\title{
林内トレイルにおいて体験された景観型と利用形態の 関係に関する研究
}

The Relationships between Experienced Landscape Types and People's Visiting Forms on a Trail in a Forest

\author{
奥 敬一* 深町加津枝* \\ Hirokazu OKU Katsue FUKAMACHI \\ 摘要 : 京都大学芦生演習林を訪れた 48 グループの一般利用者を対象として写真投影法による調查を \\ 行った。得られたデータから, 現実の森林レクリエーション行動下において体験され, 評価される森 \\ 林景観を, 視対象, 視点, 視距離, 地形, 構図などの複合的な要素からなる景観型として整理し, そ \\ れらの操作可能性を論じるとともに，景観型と来訪者の利用形態との関係を検討した。その結果，林 \\ 内散策行動の条件下で景観体験となりやすい景観のパターンが抽出された。また，レクリエーション \\ 利用者の環境に対する態度は, 異なる複数のタイプとしてとらえられ, 多様な景観体験を確保したレ \\ クリエーション地域計画の必要性が示唆された。
}

\section{1.はじめに}

良い風景との出会い，適度な運動，現代社会からの一時的離脱， 自然観察など，日常生活を離れた様々な体験を求めて，多様な層 の人々が森林を訪れる。このような多様な期待を，いかに受け入 れ，またコントロールしていくか，そして全体としていかに良質 な体験を可能にする環境を提供できるのかが，これからの森林レ クリエーション空間の計画・管理に求められている。そのため, 来訪者が森林空間の中で, どのように行動し, どのような出来事 を体験することによって満足感を得ているのかを明らかにする研 究が必要とされている。

本研究では, とくに森林内の散策で得られる景観体験に着目し, 現実の森林レクリエーションサイトにおける，実際の利用者によ る，現実に体験されたレベルで景観を把握することを目的とした。 景観体験とは，森林を訪机ることで体験する様々な出来事の一つ の形態であり，人が，環境と自らの行動との間の相互作用に伴っ て, 周囲の環境に対して風景としての意味を与え, 評価の対象と 見なすことと定義される。従って景観体験という現象は，本質的 に動的・相互作用的であり，そのため，現実のコンテクストから 離れた静的な状態に還元せずに，できるだけ動的な現象として扱 うべきもの之考えられる ${ }^{24)}$ 。その意味で, 妥当性の高い基礎的デー 夕を得るためには，できるだけオンサイトで，現実のコンテクス 卜から乘離しない調査を行うことが必要であろう。

そこで本研究においては, 写真投影法によって景観体験の実態 を把握する試みを通して, 二つの観点から林内の景観体験を論じ た。一つは，実際の林内で人間の移動に伴って現れる様々な景観 のうち，どのような景観が注目されやすく，また一般的な樹林地 を景観操作の対象ととらえた際には，その景観中のいかなる部分 の樹林地がとくに重要なのかを明らかにすることである。もう一 つは, 利用者の基本的な行動形態の違いに伴う，これら景観の認 識のされ方の相違である。

\section{2. 方法}

\section{(1) 景観体験研究の方法論}

一般的な景観体験については, 堀ら ${ }^{11)}$ や Chenowethら ${ }^{4)}$ が学 生を対象として, 自由記述式の絵や説明文の分析を行った。また, 古谷 ${ }^{7)}$ や青木' トによって調査し分析した。
これらの知見はいずれも長期記憶レベルの印象，即ち，とりわ け鮮明な景観体験が議論の対象であった。一方, 現実の活動下で は，体験時には漠然とした感動を抱きながら，長期記憶としては 残らないような，不鮮明な景観体験がある。このような，オンサ イトで連続的に生じる景観体験の把握に関しては，言語による体 験の抽出と比較して, 写真投影法が有効である。アメリカにおい ては自然地域における応用が盛んであり（例えば Cheremら ${ }^{5)}$ ), Chenoweth $^{3)}$ は初期の調査例のレビュ一から, 手法の発展の可 能性と方法論的に解決すべき点を指摘している。Hull ら 真投影法の応用として，ウィルダネスを訪れた八イカーに対して 一定時間間隔での撮影を行わせる調查を行い, 現実に遭遇した風 景や事象の分布を記録するとともに, 主観的な体験評価との関係 を調查した。また，Taylorら ${ }^{23)}$ はロッキー山脈国立公園におい て, 水際や湿地環境の景観的重要性を明らかにするために写真投 影法を応用した。韓国では, 都市近郊林において渓谷型と稜線型 のコースで景観体験の違いが明らかにされた ${ }^{21)} 。$

国内では，建築・都市計画において，計画への住民参加も交え ながら地域のイメージを簡便に収集解析できる手法として, 写真

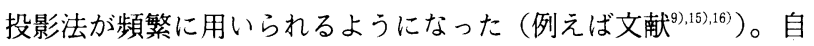
然地域を対象とした研究としては, 藤原ら ${ }^{6)}$, 比屋根ら ${ }^{10)}$ が, 学 生を被験者として森林公園施設内での調査を行い, 林内の風致解 析手法を検討した例がある。また, 筆者ら ${ }^{199}$ は都市近郊林の来訪 者を対象として認識された景観の階層性を明らかにした。

表一 1 はこれら近年の写真投影法による研究例について, 対象 とした利用者の行動と, 得られた写真デー夕の分類法を整理した あのである。一般的に写真の分類は, 中心的な被写体である撮影 対象によって行われることが多く, 撮影角度や撮影方向について の言及はみられるものの, 見る人と環境との間の立体的な関係や 構図といった複合的な要素を切り口として解析した例はみられな い。しかし, 撮影された景観は, 単に単一の視対象（被写体）だ けでなく, 複数の視対象が組み合わさり, 地形条件や視点の特性, 視距離・視線方向といった視対象との空間的関係などの複合的な 要因から成り立っている場合が多い。レクリエーション地域の計 画や林地の施業, 管理のための基礎的情報として, 写真投影法の 最大の優越性である，言語記述ではなく画像でデー夕が得られる という点を活かすには，単なる撮影対象としての記述だけではな く, 構図等の面からの具体的な森林の操作可能性を明らかにする 
表－1 写真投影法による主な研究例

\begin{tabular}{|c|c|c|c|c|}
\hline 事例 & 調查地 & 被䮎者数 & 刘象とした行動 & 写真分類法（カテゴリー） \\
\hline $\begin{array}{l}\text { 藤原 · 比屋根 · 大石 } \\
(1994)\end{array}$ & 岩手県森林公園 & 学生 7 名 & & 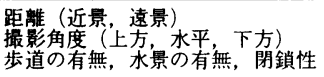 \\
\hline 比屋根·大石（1995） & 岩手県森林公園 & 学生等 8 名 & & 林相, 撮影方向, 距離 \\
\hline 奥·深町（1995） & 箕面国定公園 & 一般利用者 65 名 & $\begin{array}{l}\text { 㒉りハイク } \\
\text { 州イキンプ }\end{array}$ & $\begin{array}{l}\text { 撮影対象, 植生, 眺望, 水景, 主 } \\
\text { 篗光資源, 人物, 施設) }\end{array}$ \\
\hline Hull \& Stewart (1995) & $\begin{array}{l}\text { White River National } \\
\text { Forest (US) }\end{array}$ & 一般利用者 25 名 & 日㷌りハイク & $\begin{array}{l}\text { 枵離 (6段階) } \\
\text { 撮影对象 (景, 地面, 植生, } \\
\text { 山岳, 人物, エフェメラル) }\end{array}$ \\
\hline $\begin{array}{l}\text { Taylor, Czarnowski, } \\
\text { Sexton \& Flick (1995) }\end{array}$ & $\begin{array}{l}\text { Rocky Mountain National } \\
\text { Park (US) }\end{array}$ & 一般利用者179名 & $\begin{array}{l}\text { ハイク(日㷌り, } \\
\text { 泊りがけ) } \\
\text { キャンブ } \\
\text { ドライブ }\end{array}$ & 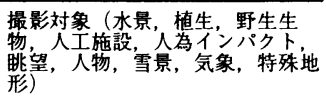 \\
\hline Park \& Oh（1998） & Mt. Apsan Park (Korea) & 一般利用者99名 & 日㷌りハイク & 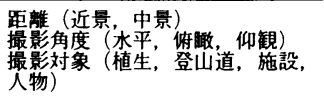 \\
\hline
\end{tabular}

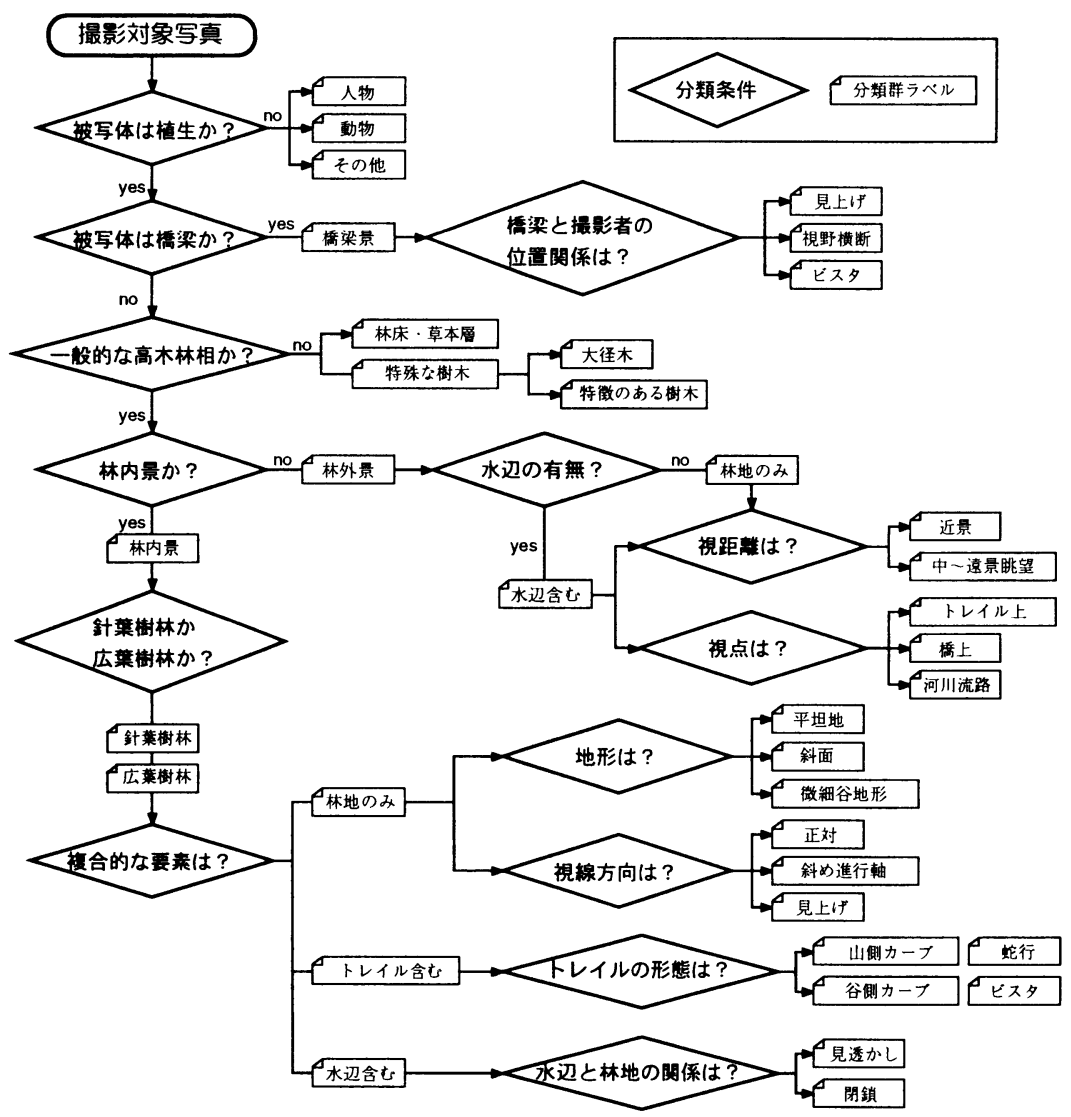

図-1 解析対象写真の分類フロー

必要があるだろう。

\section{(2) 調查地}

調査対象地として京都府美山町, 京都大学声生演習林内の由良 川本流下部のトレイルを選定した。芦生演習林は天然林が比較的 多く残された地域として知られ，一般に公開されている。調査地 の標高は約 $400 \mathrm{~m}$ であり, 沿道の植生は温帯下部に当たる落葉広 葉樹林と，スギを主体とする針葉樹人工林が混在している。また， トレイルは由良川源流の谷に沿って伸びているため, ところどこ ろ水辺にアクセスすることができる。

調査上の利点として, 分岥が少ないため全利用者にほぼ共通し た景観体験の機会が期待され，また日帰り利用の場合に往復コ一 スをとる以外に選択がないためカメラの配布・回収に適している。 また, 大都市圈から比較的交通が不便な立地にありながら, 週末 には来訪者む多く ${ }^{8)}$, 被験者のサンプルむ充分得やすい, といっ
た点があげられる。沿道はほとんど樹林 地に覆われており，一部民家や廃村跡等 ああるものの，人文的な景観資源は少な く，森林景観を主体とした景観のサンプ リングが可能である。さらに，このトレ イルは, トロッコ軌道敷として使われて いた道であるため, 平坦な道が $7 \mathrm{~km}$ 以上 にわたって続いており，急な起伏で生じ る一時的な疲労や，大きな構図の変化を 考虑する必要がない。以上のような条件 から，調查地として適当と考えた。

\section{(3) 調査の概要}

現地調查は 1998 年 5 月 30 日（土）, 31 日（日）の 2 日間にかけて行った。 いずれあおだやかな晴天日であった。

調査ではトレイルの起点（演習林事務 所前）に訪れた全来訪グループに対して 調查協力を依頼した。その内, 調査趣旨 を理解し協力に応じた被験者に対し，レ ンズ付きフィルム（以下，単にカメラと する）を配布し，良いと感じた風景を撮 影するよう指示した。また撮影は散策の 往路のみに限定した。調查に用いたカメ ラは ISO800, フラッシュ付き 27 枚撮り であり, ID ナンバーと被験者グループ の写し込みに各 1 枚を要したため, 撮影 枚数は最大 25 枚とした。カメラの配布・ 回收時に質問紙調査をあわせて行い，芦 生への来訪経験, 同伴のグループ全体の 性別・年齢構成, 来訪の目的・動機, 居 住地, 交通手段等を確認するとともに, カメラの配布・回収時刻を記録した。

被験者数は 2 日間で 48 名, 林内泊の 2 名以外は日帰り利用者であった。解析 の対象となった写真は, 露出不足等で判 別不能な 29 枚を除き，861 枚であった。

\section{3. 景観型区分と樹林の役割}

得られた写真に対して, 図一 1 に示し た分類フローに基づいて分類群のラベル 付けを行った。あらかじめ分類つローを 定義することで, 被験者に対して撮影理 由を問えない条件での写真投影法デー夕 の分類に再現性を持たせることを意四し
た。

本論では一般的な樹林地を景観操作の対象ととらえて, 構図中 の樹林地が景観的に果たす役割を探ることを目的とするため，植 生以外の被写体や，林床・草本層については比較的粗い分類にと どめた。また，橋梁は人工構造物として，森林の中ではトレイル 以上に強い焦点性を持つ要素であると考えられることから，独立 した分類とした。

このフローによって, 最終的にそれぞれの写真には 1 つから複 数の分類群ラベルがつけられた。そして，共通の分類群ラベルを 持つ景観の集合を,「景観型」と定義した。したがって,「林内景 といったより上位の分類群によるものから，「林内 $\times$ 針葉樹林 $\times$ トレイル含む $\times$ ビス夕」のように，最も末端の分類群によるもの まで，いくつかのレベルの景観型が存在する。最末端の分類群か らなる景観型は，これ以上の分類ができないことから，景観体験 


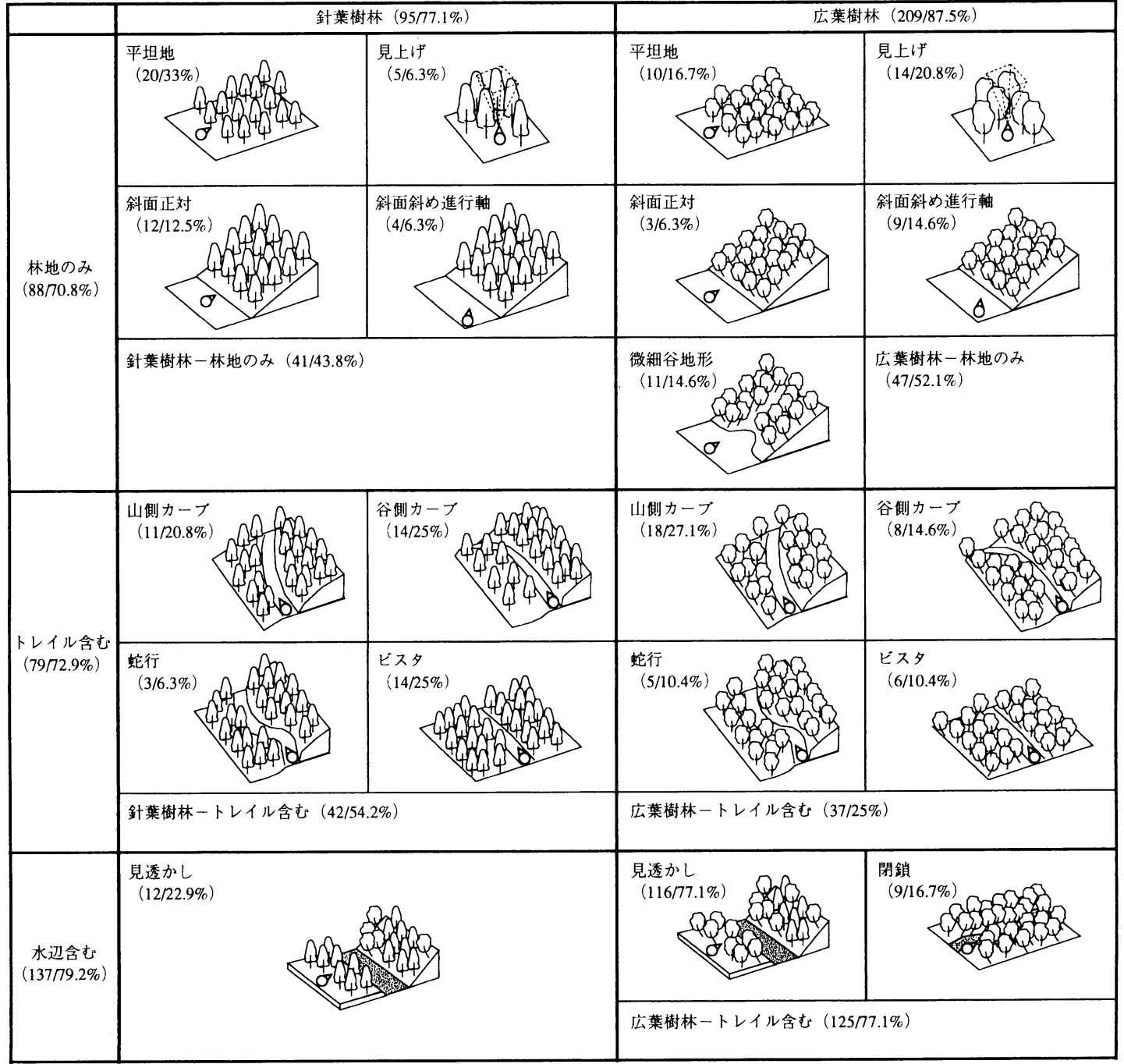

林外景 (146/87.5\%)

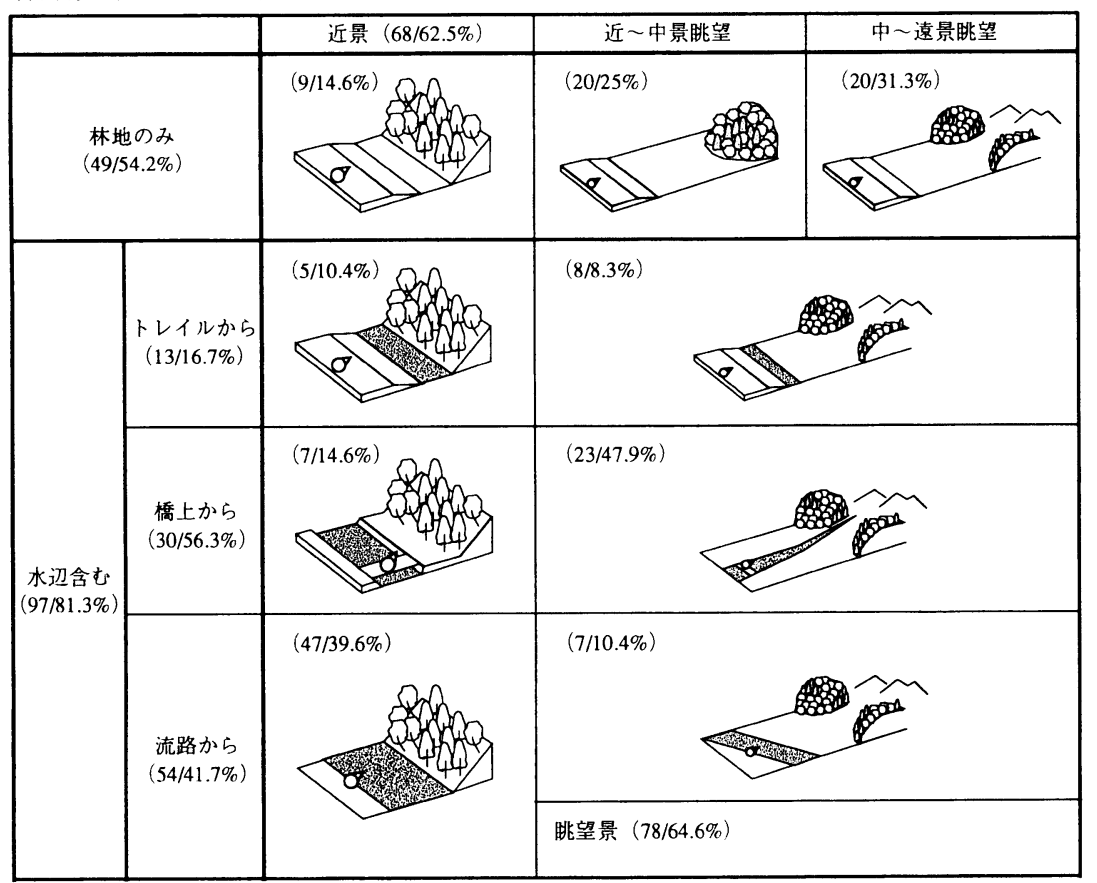

㛢梁景 $(52 / 54.2 \%)$

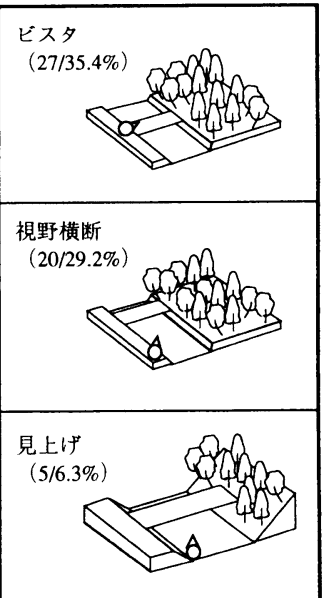

撮影者 $\bigcirc(\rightarrow$ 視線方向 $)$

水面留

数值は（撮影校数 $/$ 選択率)

図ー2 抽出された景観型の空間モデル 
の基本単位となる景観型と考えた。

操作対象となりうる一般的な樹林地空間に該当する最末端の景 観型を, 撮影枚数, 選択率 (全被験者 48 名に対する撮影者数の 割合）とあわせて, 撮影者一視環境間の空間的なモデルとして示 したのが図ー2である。図に示された以外の景観型の撮影枚数, 選択率は,「大径木」が撮影枚数 49 枚, 選択率 $47.9 \%$, 「特徵の ある樹木」が 16 枚， 29.2\%，「林床・草本層」が 211 枚，91.7\%， 「動物」が 25 枚， $20.8 \%$ ，「人物」が 7 枚，8.3\%であった。

森林を対象に撮影された景観は，一見連続的で曖昧であること が多いため, 操作対象化するための普遍的なパ夕ーン分類が提示 されることは少なかった。しかしながら，図に示されたように， これらの基本的単位となる景観型を示したことにより, 林内の散 策行動に伴って注目されやすい景観のパターンのいくつかを抽出 することができたと考えられる。これらはまた，人の意識の中で 「図」として認識されやすい部分であり, 演出することによって 高い効果が期待されるパターンといえよう。

ではそれぞれの景観型にとって樹林地はどのような意味を持っ ているだろうか。まず，林地のみからなる林内景についてみる。 「平坦地」と「斜面正対」の景観型は, 一般的に林内景観評価に 使われやすい景といえる。立木密度や枝下高, 林床植生高といっ た林内景観の操作指標は，こうした景観型を基本としているが, 選択率で見るとこれらの景観型は，林内における景観体験を部分 的にしか代表していないように思われる。また，針葉樹林と，広 葉樹林の間には撮影枚数や選択率では大きな違いはないものの, 構図的な内訳には大きな違いがみられる。「見上げ」の構図は針 葉樹林より広葉樹林でより選択率が高く, 広葉樹の樹冠が谷を両 側から覆っている「微細谷地形」は広葉樹林の場合でのみ現れる。 「平坦地」は針葉樹林の方が選択率が高く,「斜面」の場合には, 針葉樹林では正対した景観型が，広葉樹林では正対せずに斜め方 向からみた景観型が多く現れた。この対比は, 針葉樹林の景がよ り整然とした構図で好まれやすいのに対して, 広葉樹林の景は幾 何学的構図から若干逸脱した状態で好まれやすいことによると考 えられる。

トレイルを含む林内景についても,「ビス夕」のように整然性 を求められる構図には針葉樹林が多く, 広葉樹林は少なかった。 トレイルを含む景においては, トレイル上の立木のない部分がオー プンスペースとして歩行者の視線を誘導した。「山側カーブ」で は屈曲点の谷側に当たる樹林地に視線が誘導されやすいと考えら れる。一方, 「谷側カーブ」では谷側の樹林地の立木密度が高け れば, 屈曲点の山側の斜面に視線が誘導されやすく, 谷側の樹林 地の立木密度が低い状態であれば, 谷側の樹林地を見通してカー ブのさらに先に視線が誘導されるものと思われる。

水辺を含む林内景の撮影枚数は非常に多く，そのほとんどが樹 林地を通してその奥にある水面を見る「見透かし」景であった。 これは, 眺望一隠れ家理論”に相当する景である。広葉樹林では, 水辺を含む景の方がトレイルを含む景より選択率が高かった。広 葉樹林が水景との相性がよい一方, 針葉樹林ではトレイルを含む 景が水辺を含む景より選択率が高かった。これは, 整然とした林 縁を形成し植栽密度も高い針葉樹林は, 視線をトレイルの進行方 向に誘導する性質が強く出るためと考えられる。

林外景も水辺との組み合わせの景観型で選択率が高かった。さ らに視点場との組み合わせでみると, とくに橋上を視点とした場 合の眺望景の選択率が高かった。反対に流路からは近景の選択率 が高く, 水際における植生と水面の組み合わせが重要であること を伺わせる。

橋梁は視点であると同時に，林内の重要な視対象でああった。 橋を渡る際に得られるビス夕的な景観や, 橋が視野を横切る構図 は選択率が比較的高く, 背景となる樹林地とともに景観上のポイ
ントとして配慮すべきであろう。

道路の屈曲点における樹林の配置, 伐開や, 道路からの見透か し，橋の利用といった技法は，これまでにも景観演出のために有 効な手法として提言されてきた（例えば文献 $\left.{ }^{12}\right)$ )。本研究では, 実際のレクリエーション利用者がこうした技法の原形となる景観 型をかなりの程度認識していることが明らかになり，環境心理的 な観点から一般の人々がいかに森林レクリエーション地域の景観 を認識するかが示された。また，広葉樹林における「見上げ」や 「微細な谷」といった，景観的なポイントとなりうる新たなパ夕ー ンを含め, 本研究で抽出された景観型は自然地域にも導入が可能 な造園的技法と考えられる。

以上の結果の応用面としては, 本研究で確立された再現性のあ る分類フローを利用することで，サイト間での景観資源性の比較 調查などを行うことができると考えられる。また，抽出されたパ ターンが地形的に存在する地点を, 例えば $1 / 1000$ スケール程度 の地図上に落とし, GISなどで植生の状態とオーバーレイする ことで, 林内トレイルとしての適性評価や計画・管理への応用も 可能となろう。

\section{4. 利用形態と景観型との関係}

現実のレクリエーション利用時に認識される森林景観は, 来訪 時のグループ構成や主目的, 経験などによって左右されることが 指摘されている ${ }^{20)}$ 。そこで, 質問紙調査に基づく来訪目的と同伴 グループの人数から，A：少人数観察型（2名以下，観察を目的 とする), B : 少人数遊歩型（2 名以下, 観察を目的とせず, 八 イキングのみ, あるいは水辺での活動を目的とする), C：団体 観察型（3名以上, 観察を目的とする), D : 団体遊歩型（3名 以上，観察を目的とせず，八イキングのみ，あるいは水辺での活 動を目的とする）の 4 タイプに被験者の利用形態を区分して, 景 観体験の相違を検討した。少人数観察型 13 名, 少人数遊歩型 11 名, 団体観察型 13 名, 団体遊歩型 11 名であった。

図ー3には利用形態ごとに景観型の撮影枚数比率を示した。景 観型によっては, 利用形態を反映して撮影枚数比率に何点かの違 いがみられた。

林内景の撮影枚数比率は, 団体観察型の利用形態が他の形態に 比べて有意に低かった $\left(\chi^{2}\right.$ 検定, $\left.\mathrm{p}<.0001\right)$ が，少人数観察型 は林内景の撮影枚数比率が $40 \%$ を超え最も高かった。橋梁やト レイルといった林内の人工的な要素についても, 団体観察型で撮 影枚数比率が低く現れた $(\mathrm{p}<.001)$ 。また，林外景は，少人数遊 歩型で最も高く $(\mathrm{p}<.001)$, 水辺を含む景の撮影枚数比率は, 遊 歩型の形態が観察型に比べて高かった（p<.001）。一方，大径木 のように特殊な樹木は, 利用形態間で大きな違いは見られなかっ た（ $\mathrm{p}>.1) 。$ 林床・草本層は団体観察型で撮影枚数比率が高く $(\mathrm{p}<.0001)$ ，林内景の場合と対照的であった。動物の撮影枚数比 率も, 団体観察型が最も高かった $(\mathrm{p}<.0001)$ 。人物中心の写真 は少人数型の形態では撮影されなかった。

図ー4には利用形態ごとに各景観型の選択率, 撮影者 1 人当た りの撮影枚数を示した。下位のレベルでの分類による景観型の撮 影傾向と，その景観型が含まれるより上位のレベルの景観型の撮 影傾向とは異なる場合があった。

林内景の選択率はいずれの利用形態でも高く, 特に少人数観察 型で撮影者当たりの撮影枚数が多い傾向が見られた（以下，撮影 枚数の比較については $\mathrm{t}$ 検定, $\mathrm{p}<.05)$ 。林内景のうち広葉樹林 の景では選択率は団体型で高くなる傾向（以下，選択率の比較に ついては $\chi^{2}$ 検定, $\mathrm{p}<.1$ ) がみられる一方で, 撮影者当たりの撮 影枚数は少人数型が多くなる傾向 $(\mathrm{p}<.01)$ を示した。また， 卜 レイルを含む景, 水辺を含む景において観察型で選択率が低く, 遊歩型の方が選択率が高くなる傾向がみられた $(\mathrm{p}<.1)$ 。さらに, 


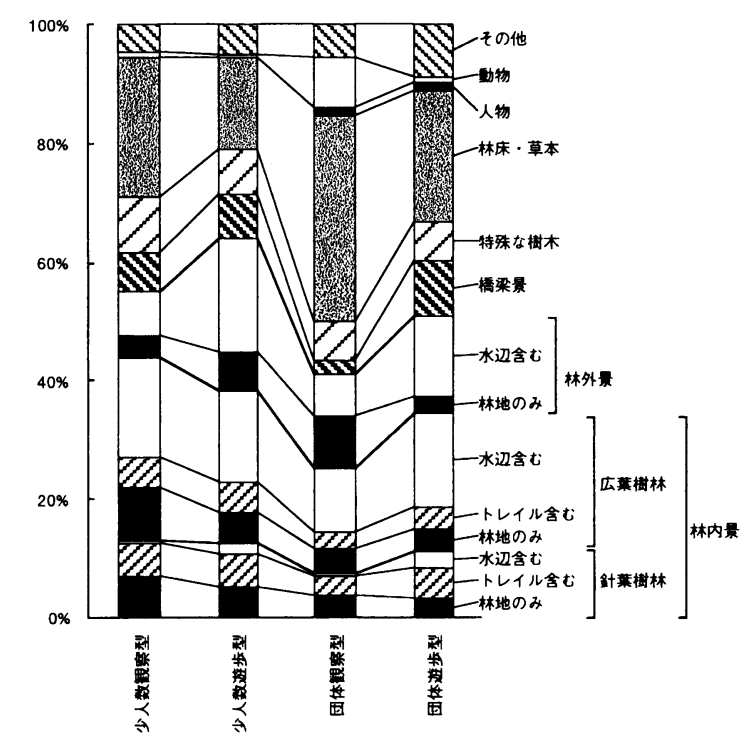

図ー 3 利用形態別にみた景観型の撮影枚数比率
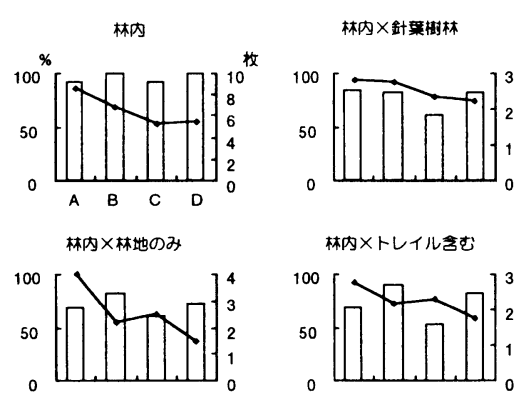

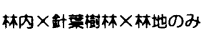

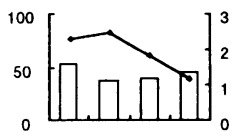

林内 $\times$ 広葉澍林 $\times$ 林地のみ

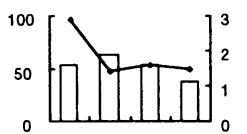

林外

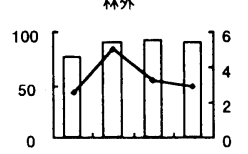

根粱

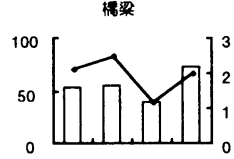

人物

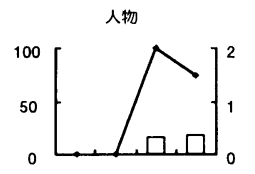

林内 $\times$ 広策樹林

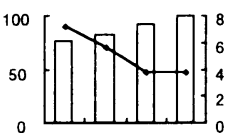

林内×水辺含む

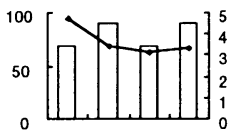

林内人針菜制林入水辺含吉

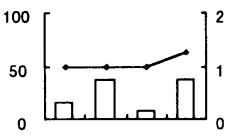

林内 $\times$ 压葉榯林 $\times$ 水迢含を

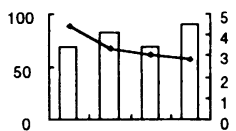

林外 $\times$ 水辺含む 林外メ林地のみ

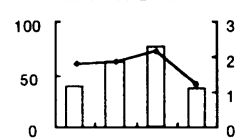

特殊な胡木

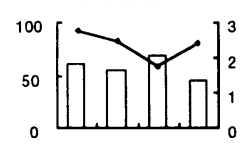

较物

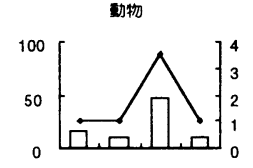

林地に複合する要素と樹種との組み合わせで検討すると，水辺を 含む景では観察型と遊歩型の差が針葉樹林の方で大きい傾句がみ られた。林地のみの景では, 少人数遊歩型において広葉樹の選択 率より針葉樹の選択率が低く，撮影者当たりの撮影枚数ではその 逆の傾向を示した。団体観察型はトレイルを含む広葉樹林の景の 選択率が低い傾向がみられた $(\mathrm{p}<.1)$ 。

林外景は少人数遊歩型で撮影者当たりの撮影枚数が多かった $(\mathrm{p}<.05)$ 。この傾向はとくに水辺を含む景で顕著であり，林地の みの場合にはそうした傾向はみられなかった。

林㦿・草本層は観察型で撮影者当たりの撮影枚数が多くなる傾 向がみられた $(\mathrm{p}<.05) 。$ 動物は団体観察型が選択率 $(\mathrm{p}<.01)$, 撮影者当たりの撮影枚数 $(\mathrm{p}<.1)$ ともに高かった。

以上のように，利用形態の違いに伴って，利用される景観資源 にも様々な相違がみられた。利用形態の 4 区分は, 人数について は，静かに自分たちのペースで行動したいか，あるいは他者との 相互関係の中で行動したいかという態度に関連すると考えられる。 また，目的については，好奇心を満たそうとするか，あるいは日 常を離れて遊びたいかという態度に関連すると考えられる。こう した態度の違いによって，選択されやすい景観型の違いについて も説明できるだろう。

例えば，団体観察型は，観察を同様に目的とする少人数のグルー プと比較して，林床・草本，動物といった比較的ミクロな景の選 択率，撮影枚数が高かったが，これは互いに類似した興味を持っ 人が何人かいる万が，興味対象を発見する確率が高いためと考え られる。また，ミクロな景に対する指向の強さが，逆に林内景の 撮影比率の少なさに現れてくるのであろう。団体観察型では，広 葉樹林内のトレイルや橋梁といった林内の人工的な要素に対し, 団体遊歩型とは対照的に選択率，撮影枚数比率が低く現れたが， これらの要素は人々の行動様式によって，必ずしも風景的な対象 と見なされないことを示している。逆に，遊歩型ではトレイルや 水辺を含む景を，遊びを誘発する要素として風景的に好ましくと らえていると考えられる。さらに, 団体型ではグループのリーダー 的立場にある人の景観の見方，興味の方向が強く影響を与えてい る可能性も指摘できる。

少人数型をみると，林内，林外あわせた林相の撮影枚数比率が 高く, よりマクロにみた森林の雾囲気を評価している。中でも, 少人数遊歩型では林外景の撮影が多く, 一歩引いて見るかたちで 森林を景観資源として利用していた。観察型や団体のグループに 比べ，行動上の制約が少ないため，水辺などの眺望がのぞめるオー プンな空間を自発的に選択し，比較的長く利用しているためでは ないかと考えられる。

Hullら ${ }^{13)}$ は，「平均的なハイカー」というものを想定すること は疑問であり，現実の利用者は環境に対して異なった反応を示す いくつかのタイプから構成されると考えるべきだとしている。本 研究の結果からも，景観の見方の違いにみられるように，被験者 の環境に対する態度による夕イプ区分は有効であると考えられる。 そして, 今後のレクリエーションサイトの計画においては, その 場所の自然環境としての特性を保全しながら，多様な価值観を持 つ多様な層に対して，様々な景観体験を許容するような配慮が求 められる。

\section{5. おわりに}

本研究によって以下の点が示された。

・林内散策行動の条件下で景観体験の対象となりやすい景観のパ ターンが抽出された。

・一般的な写真評価実験に利用できるような景観型は，林内にお ける景観体験を部分的にしか代表していない。

・その一方で, 従来からの造園的技法や理論であるビスタや見透 
かしなどに類似した景観型は, 自然地域の景観体験としても認識 されやすいことが明らかにされた。

・林地を構成する樹種の違いが景観型の選択率に影響しているこ とが示された。

・利用形態の違いによって, 利用される景観資源にも相違がみら れることが明らかにされた。

・下位のレベルでの分類による景観型の撮影傾向と，その景観型 が含まれるより上位のレベルの景観型の撮影傾向とは異なる場合 がみられた。

・レクリエーション利用者の環境に対する態度は, 異なる複数の

タイプとしてとらえられ, 多様な景観体験を確保したレクリエー ション地域計画の必要性が示唆された。

今回の報告では, シークエンスの変化による要因は考慮せずに 撮影された景観型を扱うにとどめた。今後の課題として, 景観現 象を動的な体験として扱うために，シークエンスの構成や人間の 心理的変動を含めて, より精查を行っていく必要があるだろう。

また, 写真投影法については, 他の手法との組み合わせや, 代 替手法との間での方法論的な検討む必要であろう。例えば, Hull ${ }^{14)}$ が試みたように撮影のタイミングを調查者側で指定し て体験を抽出する方法や, 大石ら ${ }^{187}$ のビデオカメラを利用者に装 着して林内体験を探る方法などとの比較により, デー夕の信頼性
や妥当性を検討する必要がある。

さらに, 本論で抽出されたそれぞれの景観型が持つ心理的, 社 会的な意味についても一層の考察が求められる。Chenoweth ${ }^{3)}$ が述べているように，カメラは一種の文化的フィルターとしての 役割を少なからず持っており, そこには時代特有の風景観が現れ ると考えられる。現代の人々が森林のある場面を写真として切り 取るという行為について深い検討が必要であろう。

\section{謝辞}

東京大学大学院新領域創成科学研究科 熊谷洋一教授, 同大学 院農学生命科学研究科 下村彰男助教授には, 研究を進める上で 貴重な示唆をいただいた。また, 森林総合研究所関西支所, 大住 克博室長には, 現地調査に多大なご協力をいただくとともに, 終 始丁寧な助言をいただいた。韓国林業研究院, 朴賛雨室長には調 査に協力いただき，さらに韓国での調查結果について日本語訳の 労を煩らわせた。京都大学演習林計画課, および芦生演習林事務 所の関係各位には, 様々な情報を提供いただき, また現地調査で の便宜をはかっていただいた。

以上の方々, そして, 調査にご協力いただいた被験者の皆様に この場を借りて篤く御礼申し上げたい。

\section{引用文献}

1）青木陽二・北村真一・近田文弘（1999）：南 アルプス登山者の風景評価：環境情報科学 28(1), 59-65

2) Appleton, J. (1996): The Experience of Landscape, Revised edition, John Wiley \& Sons, 282pp.

3) Chenoweth, R. (1984): Visitor employed photography: A potential tool for landscape architecture. Landscape Journal. 3(2), 136-143

4) Chenoweth, R. \& Gobster, H. (1990): The nature and ecology of aesthetic experiences in the landscape. Landscape Journal. $9(1), 1-8$

5) Cherem, G. J. \& Driver, B. L. (1983): Visitor employed photography: a technique to measure common perceptions of natural environments. Journal of Leisure Research.15, 65-83

6 ）藤原直子・比屋根哲・大石康彦 (1994)：レ ンズ付きフィルムを利用した風致解析手法 の検討一岩手県森林公園での実施例一：日 林東北支誌 $46,21-22$

7 ) 古谷勝則 (1998)：思い出に残る自然風景に 関する研究：ランドスケープ研究 61(5), $669-674$

8 ）枚田邦宏・竹内典之（1996）: 芦生演習林の レクリエーション利用について：京都大学 演習林報告 $68,89-99$
9 ）久隆浩・鳴海邦碩 (1992)：子供之地域空間 の関わりを分析する手法としての写真投影 法の試み:日本都市計画学会学術研究論文 集 27,715-720

10）比屋根哲・大石康彦（1995）：レンズ付きフィ ルムを利用した風致解析手法の検討 (II) 撮影地点の分布と写真の特徴一：日林東北 支誌 47,67-69

11）堀繁・栗原正夫・篠原修（1988）: 体験され た風景の構造 : 造園雑誌 51(5), 287-292

12）堀繁・斎藤蓜・下村彰男・香川隆英 (1997) フォレストスケープ: $191 \mathrm{pp}$, 社団法人全国 林業改良普及協会

13) Hull, R. B., Stewart, W. P. \& Yi, Y. K (1992) : Experience patterns: Capturing the dynamic nature of a recreation experience. Journal of Leisure Research. 24, 240 $-252$

14) Hull, R. B. \& Stewart, W. P. (1995): The landscape encountered and experienced while hiking. Environment and Behavior. 27, 404-426

15）古賀誉章・高明彦・宗方淳 - 小島隆矢・平 手小太郎・安岡正人 (1999)：キャプション 評価法による市民参加型景観調查：日本建 築学会計画系論文集 $517,79-84$

16）小島隆矢 (1997)：個人差を尊重した印象評 価 印象の工学: 現代のエスプリ 364, 99127

17）野田正彰（1988）：漂白される子供たち：情
報センター出版, 205pp.

18）大石康彦・比屋根哲（1995）：森林内体験解 析手法の検討一小型ビデオカメラを利用し た解析一：日林東北支誌 47, 71-72

19）奥敬一・深町加津枝（1995）：写真投影法に よる箕面国定公園利用者の風景認識に関す る研究：ランドスケープ研究 58(5)，173176

20）奥敬一・深町加津枝（1999）：レクリエーショ ン利用者の活動・属性・風景認識：第 110 回日本林学会大会学術講演集, 404-405

21) Park, C., \& Oh, J. (1998) : Study on the characteristics of landscape of urban forest (II). FRI Journal of Forest Research. 58, 104-113. (in Korean with English abstract)

22）杦浦理子・山本聡・下村泰彦・増田昇 （1999）: 居住者の日常風景に対する喍好性 と地区の歴史的蓄積之の関わりについて : ランドスケープ研究 62(5)，677-680

23) Taylor, J. G., Czarnowski, K. J., Sexton, N. R. \& Flick, S. (1995): The importance of water to Rocky Mountain $\mathrm{Na}$ tional Park visitors: An adaptation of visitor-employed photography to natural resources management. Journal of Applied Recreation Research. 20(1), 61-85

24）吉村晶子 (1998)：「東関紀行」の分析を通 じた動態的風景記述モデルの構築：ランド スケープ研究 61(5), 675-680

Summary : Using Visitor Employed Photography, every photo spot taken by 48 groups which visited Kyoto University Forest in Ashu on May, was analyzed to discuss the operational possibility of forest landscapes and relationships between landscape types and attributes. Forest landscapes, which were experienced and evaluated by people through forest recreation, were classified into 38 landscape types according to the compositional elements of landscapes, such as visual object, view point, visual distance and topography. From our results, it was clarified that people frequently took a series of scene spots composed by several landscape types, which differed from people's visiting forms such as size of their groups and purpose to visit. 